\title{
The Effect of Problem-Based Learning Models Using Mind Map to Improve Critical Thinking and Problems Solving Skill of Student
}

\author{
Novita \\ Physics Education Program \\ Graduate program, Universitas Negeri Medan \\ Medan, Indonesia \\ novita.ichsanbasuki@gmail.com
}

\author{
Nurdin Bukit \\ Physics Education Program \\ Graduate program, Universitas Negeri Medan \\ Medan, Indonesia \\ nurdinbukit5@gmail.com
}

\author{
Makmur Sirait \\ Physics Education Program \\ Graduate program, Universitas Negeri Medan \\ Medan, Indonesia \\ makmursirait@yahoo.com
}

\begin{abstract}
This study aims to analyze the critical thinking skills and problem-solving skills, analyzing whether the improvement of critical thinking skills and problem-solving skills that are taught by the problem-based learning model using mind map better than students who are taught by conventional learning. This research is a quasi-experimental research with two group pretest-posttest design. The research population is all students of class X SMA Negeri 2 Bandar (senior high school) in first semester, academic year 2017/2018. The study sample was taken randomly consisting of 64 students. Class X MIPA-1 is an experimental class, consisting of 32 students with learning problem model learning using mind map. Class X MIPA-3 is a control class consisting of 32 students using conventional learning. The research instrument uses essay test of critical thinking skills and problem-solving skills that have been declared valid. Data analysis using statistical t-test. The results showed that the average value of critical thinking skills and problemsolving skills using conventional learning was 61.09 and 61.88 were in a low category while the students applying the problembased learning model using mind map were 75.78 and 77.56 are in the moderate category. The result of hypothesis testing using independent sample t-test shows that each significance value (sig) $<0.05$ is 0.00 then $H_{0}$ is rejected, it means that the skills of critical thinking and problem-solving skills of students who are treated with problem-based learning model using mind map is better than conventional learning, so it can be concluded that there is the effect of problem based learning model using mind map to improve critical thinking skills and problem-solving skills.
\end{abstract}

Keywords- problem based learning model; mind map; critical thinking skills; problem-solving skills

\section{INTRODUCTION}

The development of science and technology is very rapid at this time cannot be separated from the progress of physics that many produce new findings in science and technology.
Physics, in this case, is placed as one of the important subjects because of one of the requirements mastery of science and technology related to natural science which includes physics. This means that physics has an important role in the progress of science and technology [1].

Learning physics requires problem-solving, this is confirmed by [2] which states that problem-solving efforts and the application of meaningful knowledge should give priority to positive attitudes and efforts to understand it. Based on the theoretical explanation, then a conceptual understanding is as a representation of learning outcomes, which becomes very important in learning physics is the skills of students in solving problems.

Physics learning process in high school at this time, in general, has no impact on critical thinking skills and solve student problems. Physics Learning largely emphasizes only aspects of the product such as memorizing concepts, principles or formulas and does not involve opportunities for students to be actively involved in the processes of physics so that they cannot grow students' scientific attitude.

Based on the observations in SMA Negeri 2 Bandar, Simalungun district found some problems in the learning process. First, the study of physics contains many abstract principles, concepts, and theories difficult to understand by students. Second, students are less optimal in the learning process that causes unbalanced cognitive abilities, effective and psychomotor students. Most of the students are also unable to relate between what is learned and its meaning which causes the students to get used to thinking less which causes the skills to solve fewer student problems. Third, the critical thinking skills that appear in the learning process are just aspects of asking and answering questions from the teacher and the frequency is still small. Fourth, the selection of learning models and learning methods that are learned does not match the learning materials. Of the several problems resulted in many students who obtain learning outcomes less 
than the limit of mastery and critical thinking skills of students to be not good, students are still less skilled at solving a problem. Students use only one sourcebook. Students do not try to find other references to enrich their discussion in completing the task.

One effort to improve the skills of critical thinking and problem-solving skills is by applying the learning model that includes the characteristics of students, the material characters, and resources possessed, it is a problem-based learning model. [3] Argues that the problem-based learning model is one of the learning models that develop thinking skills such as critical thinking and problem-solving skills, learning the roles of adults and becoming independent learners. The problem-based learning model is characterized by students working with other students, most often in pairs or in the form of small groups.

One of the learning media that can be used to assist students in understanding the basic concept of physics is Mind Map. With Mind Map, a long list of information can be made into a color chart, very regular, and easy to remember that works in accordance with the natural workings of the brain in doing things [4].

Through research journals such as those conducted by [5], [6], [7], [8] stated that the problem-based learning model positively impacts problem-solving skills, and student learning outcomes. Meanwhile, according to [9] that problem-based learning model can improve students' critical thinking skills and [10], [11] stated that the problem-based learning model can increase students' critical thinking skills and problemsolving skills.

\section{RESEARCH METHOD}

This research has been conducted in SMA Negeri 2 Bandar, Simalungun district, class X of MIPA in the first semester of the academic year 2017/2018. The population in this study is all students of class X MIPA SMA Negeri 2 Bandar, after random sampling is selected class X MIPA 1 as experimental class and class X MIPA 3 as a control class.

This study included quasi experimental research with design: two group pre-test post-test design [12]. The instrument used to measure the critical thinking skills of students is essay test and the indicator of critical thinking skills used in this research which refers to five indicators, which are: simple explanation, build basic skills, conclude, make further explanation, strategies and tactics and the problem solving skill instrument in this study was made in the form of essay test.

\section{RESULT AND DISCUSSION}

\section{A. Pretest data of critical thinking skills and Problem Solving Skills}

Description of pretest data presented in the results of this study is an early description of the critical thinking skills of students who made the subject of research before being treated. In summary the results of critical thinking skills pretest in this study are presented in table.
TABLE I. Data Pre-Test Of Critical Thinking Skills

\begin{tabular}{|c|c|c|c|}
\hline \multicolumn{2}{|c|}{ Control Class } & \multicolumn{2}{c|}{ Experiment Class } \\
\hline Value & Frequency & Value & Frequency \\
\hline $10-16$ & 4 & $10-15$ & 3 \\
\hline $17-23$ & 4 & $16-21$ & 4 \\
\hline $24-30$ & 15 & $22-27$ & 8 \\
\hline $31-37$ & 6 & $28-33$ & 7 \\
\hline $38-44$ & 1 & $34-39$ & 4 \\
\hline $45-52$ & 2 & $40-45$ & 6 \\
\hline average & 27,97 & Average & 28,59 \\
\hline
\end{tabular}

Based on table I shows that the mean of the students' critical thinking skills in the experimental class is 28.59 and for the control class is 27.97 . The mean values of each class were not significantly different.

Description of pre-test data presented in the results of this study is a preliminary description of problem solving skills on students who made the subject of research before being treated. The result of pre-test problem solving skills data of control class and experiment class can be seen in table.

TABLE II. Data Pre-Test Of Problem Solving Skills

\begin{tabular}{|c|c|c|c|}
\hline \multicolumn{2}{|c|}{ Control Class } & \multicolumn{2}{c|}{ Experiment Class } \\
\hline Value & Frequency & Value & Frequency \\
\hline $18-25$ & 6 & $18-25$ & 7 \\
\hline $26-33$ & 9 & $26-33$ & 6 \\
\hline $34-41$ & 12 & $34-41$ & 9 \\
\hline $42-49$ & 2 & $42-49$ & 3 \\
\hline $50-57$ & 2 & $50-57$ & 6 \\
\hline $58-65$ & 1 & $58-65$ & 1 \\
\hline average & 34,69 & Average & 36,68 \\
\hline
\end{tabular}

Based on table II indicates that the average problem solving skills of the experimental class students is 36.68 and the control class is 34.53 . The mean of each class did not differ significantly.

\section{B. Post-test data of critical thinking skills and problem solving skills}

Description of post-test data presented in the results of this study is a description of critical thinking skills students after being treated. In summary the results of critical thinking skills post-test in this study are presented in figure.

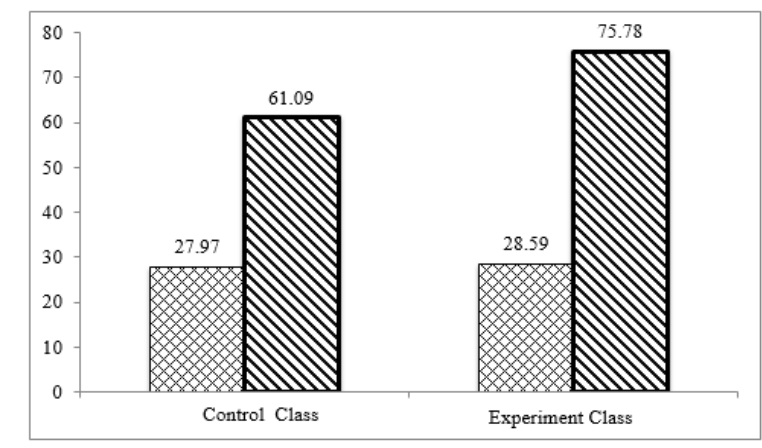

Fig I. Average pre-test and post-test of critical thinking skills 
The experiment class has the best mean value of critical thinking skills compared to the mean values of control class critical thinking skills. The mean improvement of critical thinking skills in the experimental class was caused by the teacher applying the model of problem based learning using mind map.

The critical thinking skills tests that have been answered by the students are analyzed per item. This analysis is useful to look at which student's critical thinking skills indicators are the difficulties for the students shown in table.

TABLE III. The Average Score Of Students' Answers Per Point About Critical Thinking Skills

\begin{tabular}{|c|c|c|c|}
\hline \multirow{2}{*}{ Indicators } & \multirow{2}{*}{$\begin{array}{c}\text { Maximum } \\
\text { Score }\end{array}$} & \multicolumn{2}{|c|}{ Class } \\
\cline { 3 - 4 } & & Control & Experiment \\
\hline Simple explanation & 4 & 2,91 & 3,19 \\
\hline Build basic skills & 4 & 3,03 & 3,25 \\
\hline Conclude & 4 & 2,69 & 3,47 \\
\hline Make further explanation & 4 & 1,97 & 2,84 \\
\hline Strategies and tactics & 4 & 1,63 & 2,41 \\
\hline
\end{tabular}

Based on table III shows that the difference of students' knowledge in each indicator of students' critical thinking skills in the control class and experimental class. The maximum achievement of each indicator of the critical thinking skills of the experimental class indicates a better value.

The post-test result of student problem solving skills in the control and the experiment class is shown in Figure.

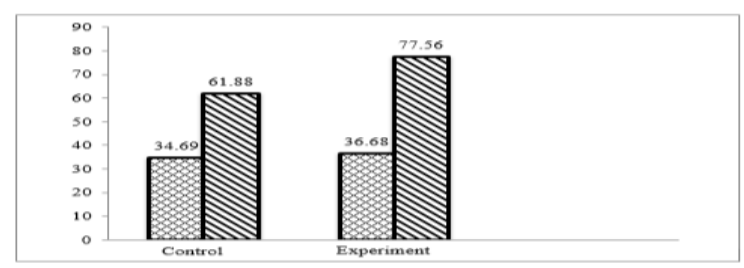

Fig 2. Improved pre-test and post-test average of problem-solving skills

The experiment class has the average of the best problem solving skills compared to the average of the control class problem-solving skills. The increase of average problem solving skills in the experiment class is caused by the teacher applying the model of problem based learning using mind map.

Problem solving skills that have been answered by students are analyzed in each item. This analysis is useful to look at which student problem-solving skill indicators are difficult for students, the results shown in table.
TABLE IV. Average Score Of Students' Answers In Each Item Of Problem Solving Skills

\begin{tabular}{|c|c|c|c|}
\hline \multirow{2}{*}{ Indicators } & \multirow{2}{*}{$\begin{array}{c}\text { Maximum } \\
\text { Score }\end{array}$} & \multicolumn{2}{|c|}{ Class } \\
\cline { 3 - 4 } & & Control & Experiment \\
\hline Understanding the problem & 20 & 14,44 & 16,44 \\
\hline Interpreting the problem & 20 & 14,28 & 16,09 \\
\hline Designing a strategy & 20 & 13,09 & 16,00 \\
\hline Implementing the strategy & 20 & 11,13 & 14,53 \\
\hline Evaluate the solution & 20 & 9,41 & 14,50 \\
\hline
\end{tabular}

Based on table IV shows that students' knowledge differs in each student's problem solving skills indicator in the control and experimental classes. The maximum achievement of each the indicator of problem solving skills in experiment class indicates a better grade.

\section{Discussion}

Based on the first hypothesis states that the critical thinking skills of students with problem-based learning model using mind map better than the critical thinking skills of students use conventional learning caused by [13] states that the problem-based learning model provides opportunities for students to develop their skills and critical thinking skills through complex problem-solving processes in small discussion groups, so that students' analysis, interpretation, evaluation, inference and explanation skills are better, and [14] argued that the problem-based learning model is very important in teaching science because it can improve the emotional domain of student learning process, improve student performance on complex tasks, and foster better retention of knowledge.

Besides [15] describes the PBL process begins by reading the problems from the real world that make the students more interested, and ends with presentations and discussions of what is found. These activities train students' critical thinking skills especially aspects of skills building, concluding, further explanation and tactical strategies. In line with [16] states when a teacher applies problem based learning model, problem-based learning process will cause a shift in focus from teacher to student. Learning outcomes are expected when students focus on the problems it will appear the skills of students to think critically and even skillfully to solve problems.

Another cause is that every phase in the problem based learning model leads students to think critically. For example, in the third phase of the problem-based learning model that helps independent and group investigations lead students to collect information on the problems given by the teacher, carry out the experiment with the actual until they fully understand the dimensions of the problem situation. After collecting enough data then students will offer hypotheses, explanations and solutions. In this phase the indicator of critical thinking skills is to build basic skills and conclude will 
be improved. In line with [17], the increase of critical thinking with problem based learning model is in moderate category, while control class using conventional learning is in very low category.

Increased students' critical thinking skills in the problembased learning model caused students to be more careful in analyzing a problem, the skills to express ideas in groups and between groups. The statement is supported by [18], students express themselves differently, producing many different answers, but attempts are made to unite of different opinions into a solution of the problem.

Furthermore, problem-based learning model improves critical thinking skills because students have positive effects and interest in the topic being taught with the phases of the problem-based learning model. Students in the PBL class using mind map, the material taught with mind map in the form of a summary of the subject matter that has been prepared. At this stage the mind map created must be interesting and easier for students to remember the material and the formula contained in the mind map and able to improve the quality of learning through thinking process. This is in line with the findings of [19] that the mind map or concept map can improve the quality of student physics learning because in the concept map has been contained concepts lessons that can be easily understood.

Based on the second hypothesis states that the problem solving skills of physics students using problem-based learning model is better than the problem-solving skills of students who use conventional learning. Students using problem-based learning model have better quality in providing solution to a problem, seen from the achievement of problem solving skill indicator of each class. In line with the [20] for the problem-based learning group, the average rating was 35.50 compared with the non-problem-based learning group, 15.50

In Learning model of problem-based learning, students will learn group work, so students can freely exchange ideas with their respective groups, so that students will have problem solving skills. In accordance with the research of [21] concluded that collaborative learning can provide strong support to develop student problem solving skills because students can share knowledge and interact with members of each group. This is also stated by the findings of [22] that problem-based learning activities will improve problemsolving skills because the problem-based learning modeling activities encourage students to deal with problems and think strategically in order to solve problems.

Problem-based learning model is better than conventional learning, because students learn the group. When students are studying in groups then students are developing social skills, self-learning exercises, self-esteem is increasing in line with [20] states that the problem-based learning model is a more effective teaching method for teaching physics compared with conventional teaching methods. This is because students in the experimental group perform better than the students found in the comparison group.
The cause of using problem based learning model using mind map can improve student problem solving skill according to the invention of [23], that when the problembased learning model combined with mind map techniques will add concept knowledge so that students can more easily remember the material being taught. Thus based on the above explanation the combination of problem-based learning model with mind map significantly influence students to have problem solving skills so that it can be applied as an alternative in physics learning.

\section{CONCLUSION}

Critical thinking skill of student who applied with problem based learning model using mind map is better than students who are applied by conventional learning, based on the average score of students obtained in the experiment class of 75.78 and the control class of 61.09 and student problemsolving skill applied with problem-based learning models using mind map is better than who are applied by conventional learning, based on the average score of students obtained in the experimental class of 77.56 and the control class of 61.88 .

\section{References}

[1] Eldy., And Sulaiman, F, "Integral PBL Approach: Premilinary Findings Towards Physics Stident's Critical Thinking and Crative Critical", International Journal of Humanities and Social Science Invention, 2013, Vol.2, pp.18-25

[2] Santyasa, I. W, "Metode Penelitian Pengembangan dan Teori", Moduls, Universitas Pendidikan Ganesa, 2009.

[3] Arend. R, "Learning To Teach". Yogyakarta: Pustaka Pelajar, 2008.

[4] Buzan, T, "Buku Pintar Mind Map", Jakarta : Gramedia Pustaka Utama, 2012.

[5] Mukhopadhyay, R, "Problem Solving In Science Learning Some Important Considerations of a Teacher" IOSR Journals Of Humanities And Social Scince, 2013, Vol. 8, pp.21 - 25

[6] Elvan, "Effects of Problem Solving Method on Science Process Skills and Academic Achievement", Journal of Turkish Science Education., 2010, Vol.7, pp.13-25.

[7] Adeyemo, S.A, "Strudent's Skills Level and Their Competence in Problem Solving Task in Physics", International Journal of Educational Research and Technology, 2010, Vol.-, pp.35-47.

[8] Lubis, R,H., Sahyar, "Efek Model Pembelajaran Berbasis Masalah Terhadap Hasil Belajar Siswa Pada Materi Listrik Dinamis Di Kelas X Semester II SMA Negeri 1 Hinai Kabupaten Langkat TA 2013/2014”, Jurnal Inpafi, 2015, Vol.3, pp.124-131.

[9] Cotton, C, "Problem Based Learning in Secondary Science". The Australian Journal of Science, 2011.

[10] Dwijananti, P, "Pengembangan kemampuan berpikir kritis mahasiswa melalui Pembelajaran problem based instruction pada mata kuliah Fisika lingkungan”, Jurnal Pendidikan Fisika Indonesia, 2010, Vol.-, pp.108 114.

[11] Panjaitan, P, "Penerapan Model Pembelajaran Berbasis Masalah (PBL) Dengan Bantuan Peta Konsep dan Sebagai Upaya Meningkatkan Pemahaman Konsep dan Pemecahan Masalah Matematika", Thesis published, 2010, Medan: PPs UNIMED.

[12] Arikunto, "Dasar-dasar Evaluasi Pendidikan”, Jakarta: Bumi Aksara, 2009.

[13] Ersoy, E and Nese, "The effects of Problem Based Learning Method in Higher Education on Creative Thinking", Procedia Social and Behavioral Sciences, 2014, Vol.11, pp.3494 - 3498. 
[14] Allen, D. E., Donham, R. S., and Bernhardt, S. A, "Problem based learning", New Directions for Teaching and Learning, 2011, Vol.128, pp.21-29.

[15] Osman, K., dan Kaur, S. J, "Evaluating Biology Achievement Scores in an ICT Integrated PBL Environment" Eurasia Journal of Mathematics, Science \& Technology Education, 2014, Vol.10, pp.185-194.

[16] Carriger, M, "Problem based learning and management development: empirical and theoretical considerations" International Journal of Management Education, 2015, Vol.13, pp.249-259.

[17] Ayuninggrum, D and Sri , M,E,S, "Pengaruh Model Problem Based Learning terhadap Keterampilan Berpikir Kritis Siswa SMA Pada Materi Protista", Jurusan Biologi, FMIPA, Universitas Negeri Semarang, Indonesia, 2015, [Online] Available https://journal.unnes.ac.id/artikel_sju/ujbe/8904, (July 17, 2017).

[18] Sinprakob,S dan Noawanit Songkram., "A proposed model of problem based learning on social media in cooperation with searching technique to enhance critical thinking of undergraduate students", Procedia Social and Behavioral Sciences, 2015, Vol.174, pp.2027 - 2030

[19] Yogihati, "Peningkatan Kualitas Pembelajaran Fisika Umum Melalui. Pembelajaran Bermakna Dengan Menggunakan Peta Konsep”, Jurnal Pendidikan, Fisika Indonesia, 2010.
[20] Argaw, Aweke Shishigu., Beyene Bashu Haile, Beyene Tesfaw Ayalew and Shiferaw Gadisa Kuma, "The Effect of Problem Based Learning (PBL) Instruction on Students Motivation and Problem Solving Skills of Physics" EURASIA Journal of Mathematics Science and Technology Education, 2016, Vol.13, pp.857-871.

[21] Laisema, S. dan Wannapiroon, P, "Collaborative Learning with Creative Problem Solving Process Learning Activities in a Ubiquitous Learning Environment to Develop Creative Thinking Skills" Journal Procedia Social and Behavioral Sciences, 2014, Vol.116, pp.3921-3926.

[22] Phumeechanya, N dan Panita Wannapiroon, "Design of Problem Based with Scaffolding Learning Activities in Ubiquitous Learning Environment to Develop Problem Solving Skills", Procedia Social and Behavioral Sciences, 2014, Vol. 116, pp.4803 - 4808.

[23] Arahmat, Y., Suratno, Bevo, W, "The Effect Of Problem Based Learning Model With Mind Mapping Technique On Biology Learning Achivement" FKIP Universitas Jember, Pancaran Pendidikan, 2017, Vol. 6, pp.125-132. 